\title{
Preliminary risk assessment of common-use pesticides using PRIMET and PERPEST pesticide risk models in a semi-arid subtropical region
}

\author{
W Malherbe ${ }^{1 *}$, JHJ van Vuren ${ }^{1}$ and V Wepener ${ }^{2}$ \\ 'Centre for Aquatic Research, Department of Zoology, University of Johannesburg, PO Box 524, Auckland Park, 2006, South Africa \\ ${ }^{2}$ Water Research Group (Ecotoxicology), Research Unit for Environmental Science and Management, School of Biological Sciences, \\ Potchefstroom Campus, North-West University, Private Bag X6001, Potchefstroom, 2520, South Africa
}

\begin{abstract}
The pesticide risk in agriculture in developing countries has not been adequately studied due to the extent and fate of pesticides in the environment often being unknown. South Africa is a country that has significant pressure on its freshwater and agricultural resources, which increases the possibility of pesticide effects. Thus, the aim of this study was to evaluate the use of the PRIMET (Pesticide Risks in the Tropics to Man, Environment and Trade) and PERPEST (Predicting the Ecological Risk of PESTicides) models to predict pesticide exposure and effects on aquatic ecosystems due to spray drift. Vaalharts Irrigation Scheme is situated in the Northern Cape Province and receives water from the Vaal River for 43000 ha of agricultural land. Crops in the area mostly consist of wheat, maize and groundnuts. Data gathered through household surveys with farmers were used in PRIMET as a first-tier estimate of the potential risk of the pesticides. The Predicted Effect Concentrations (PEC) calculated for the pesticides indicating a possible to definite risk were then used as input for PERPEST. PERPEST is a higher-tier model that predicts the potential effects of a pesticide on various grouped endpoints in the aquatic environment. The PRIMET results indicated most pesticides posed no risk to the environment, except the pyrethroid, deltamethrin. The ETR for deltamethrin indicated a possible to definite risk to the aquatic environment. The PERPEST results for deltamethrin indicated a high probability of clear effects on insects, micro- and macro-crustacean communities, with a lower probability for rotifers, algae, macrophytes and fish. PRIMET and PERPEST provided valid estimates of risk for pesticides and could be used effectively in South Africa.
\end{abstract}

Keywords: pesticides, PRIMET, PERPEST, Vaalharts

\section{INTRODUCTION}

In most countries the use of pesticides in agriculture is an accepted practice as it ensures a reliable yield of good quality produce. However, the extensive use of pesticides in developing countries quite often goes along with improper use (Ecobichon, 2001; Damalas and Eleftherohorinos, 2011). The pesticides can enter the aquatic ecosystem through various routes such as spray drift or runoff (Raschke and Burger, 1997; Schulz, 2004). This may then pose risks to various non-target organisms in the aquatic ecosystem that can cause effects at population, community and ecosystem levels. Pesticides potentially affect human health through the consumption of fish, water and macrophytes from affected surface water (Van den Brink et al., 2005). Therefore it is important to assess the risk posed by the multitude of different pesticides that are used within the agricultural communities at this point in time.

There are various models being used to predict ecological risk of pesticides, including population, food-web and ecological models (Koelmans et al., 2001; Traas et al., 1998; Van den Brink et al., 2007). However, these models are quite often intricate and complex with a large number of input parameters required. Quite often the detailed data needed for these models are not available, and the models often focus only on certain risk aspects, making their applicability limited. The resulting

\footnotetext{
* To whom all correspondence should be addressed.

용 +27 11559 3820; Fax: +27 11559 2286;

e-mail: malherbewynand@gmail.com

Received 25 May 2012; accepted in revised form 14 August 2013.
}

outcome of this is complex simulation models that are inaccurate due to the primary input data being insufficient (Van den Brink et al., 2006). This is amplified in developing countries due to a lack of resources, thus restricting widespread use of the models (London et al., 2005).

To overcome the limitations of the various pesticide models that are currently available the PRIMET (Pesticide Risks in the Tropics to Man, Environment and Trade) and PERPEST (Predicting the Ecological Risk of PESTicides) models were created. The aim was to create models that have a wider scope for application, need a limited number of input parameters and are cost effective (Ansara-Ross et al., 2008). The resultant models are also easy to use making it possible for people without specialist training to use and predict the risk of pesticides to the environment.

The PRIMET Decision Support System was created to predict the risk of pesticide application to aquatic life, terrestrial life, use of groundwater for drinking water as well as dietary exposure (Van den Brink et al., 2005). PRIMET estimates the risk at household level, using actual pesticide application data gathered from a situation analysis, and only the risk of pesticides to surface water (due to spray drift) is taken into account. PRIMET was developed and applied in developing countries in south-east Asia (Thailand and Sri Lanka). The PRIMET version 1.0 model that was implemented in these countries yielded a relatively worst-case scenario risk assessment that required limited input data (Satapornvanit et al., 2004). It is important to note that PRIMET only accounts for risk due to spray drift and therefore the risk might be an underestimation as runoff processes are not incorporated. 
A higher-tier risk assessment can include laboratory tests with realistic exposure regimes, toxicity testing of indigenous species, toxicity testing in model ecosystems as well as the use of various models that include population, food-web and landscape models (Campbell et al., 1999). Brock et al. (2000a; $2000 \mathrm{~b})$ reviewed published microcosm and mesocosm experiments on the effects of herbicides and insecticides to determine ecological threshold values for pesticides in aquatic ecosystems. This review formed the basis of the PERPEST database. The higher-tier risk model used in the preliminary risk assessment is the PERPEST model (Van den Brink et al., 2002; Van Nes and Van den Brink, 2003; Van den Brink et al., 2006). PERPEST predicts the potential toxic effects of a specific pesticide concentration on various grouped endpoints using a case-based reasoning (CBR) approach. The CBR approach uses past experience to predict or solve new problems. The endpoints used for predicting effects on insecticides are: algae and macrophytes, rotifers, insects, micro-crustaceans, macro-crustaceans, other invertebrates, fish and community metabolism. Macrophytes, periphyton, phytoplankton, zooplankton, insects, molluscs and macro-crustaceans, fish and tadpoles and community metabolism are the endpoints used for evaluating herbicides (Van den Brink et al., 2006). All of the endpoints are structural endpoints except for community metabolism which represents a functional endpoint.

In South Africa, very little work has been done in terms of pesticide risk assessment, with the majority of work focused on the estuaries and rivers of the Western Cape (Schulz, 2001; Bollmohr, 2007). Ansara-Ross et al. (2008) adapted the PRIMET (Van den Brink et al., 2005) and PERPEST (Van den Brink et al., 2002) models for South African conditions in the Crocodile (West) Irrigation Scheme. The results of the adaption study indicated that the model is effective in predicting risks in the aquatic ecosystem as it is user-friendly with data being easily accessible. It was also found that this probabilistic approach is a significant improvement over the use of safety factors and simulation models and that the models have significant scope for application in ecological risk assessment in South Africa. The aim of this paper was to implement the PRIMET and PERPEST models in a different irrigation scheme in South Africa to determine a preliminary risk assessment.

The Vaalharts Irrigation Scheme (VHIS), located in the semi-arid Northern Cape Province of South Africa, in the Harts River valley, was selected as an additional validation area. The irrigation scheme is fed from the Vaal River and the return flow enters the Harts River. This area of South Africa does experience pressure on its water resources due to the low annual rainfall and the decreased water quality it receives from the Vaal River draining from Gauteng (DWAF, 2004). The main crops in this area are wheat, lucerne, maize and groundnuts, with a wide range of pesticides currently being used from planting until harvest time. The intense cultivation and pesticide use in the area (Raschke and Burger, 1997), as well as upstream of the area, make it a suitable area to implement the models, as it will indicate if the models can highlight the potential risk in the area without taking into consideration the upstream pesticide usage.

\section{METHODS}

The preliminary risk assessment was carried out by using the PRIMET model as a first-tier estimation of the potential risk of each pesticide to the aquatic ecosystem associated with the VHIS. The PRIMET model provided a Predicted Effect Concentration (PEC) of the pesticides in question. Higher-tier risk estimation was implemented on the pesticides for which a possible or definite risk to the aquatic ecosystem was indicated. The higher-tier risk estimation was carried out using the PERPEST model by using the PEC to determine the potential effects on aquatic endpoints.

The PRIMET model requires that physico-chemical parameters of the active ingredients are available. These include toxicity data, dissipation times, and sorption characteristics. The model is applicable in warmer areas as parameters that have a temperature dependence (vapour pressures, solubility) have been accounted for within the exposure assessment. The specific pesticide application schemes practiced by the farmers have to be determined in terms of dosage, number of applications and time between applications. The physical scenario of the water body also has to be estimated in terms of the flow velocity, geometry of canals, and organic matter within the canals (Van den Brink et al., 2005).

The risk is expressed in Exposure Toxicity Ratio's (ETR) which is the estimated exposure concentration divided by the safe concentration (Van den Brink et al., 2005). The exposure concentrations are a worst-case scenario estimated from the specific local conditions. The safe concentrations are calculated by using toxicity data and safety factors. If the estimated ETR is smaller than 1, the risk is acceptable. If the ETR is larger than 1 but smaller than 100, there might be a risk present. If the ETR is higher than 100, a definite risk is present based on worst-case assumptions. If the ETR is higher than 1 a higher-tier risk assessment (PERPEST) is carried out to determine the real risk.

The PERPEST model uses the toxicity database to find analogous experiments so that it can predict the effect of specific concentrations of a selected pesticide. These past experiments are selected based on their relevant toxicity characteristics, exposure concentrations and type of ecosystem (Van den Brink et al., 2006), thus allowing the model to use other pesticides' information to predict effects of the specific pesticide. A controlled random search procedure can be used to optimise the parameters used in the prediction (Van den Brink et al., 2002). The results of the prediction for a pesticide at a specific concentration are showed as the probability of no, slight or clear effects on the various grouped endpoints. These various endpoints provide a more realistic estimation of the effects for pesticides indicating a possible or definite risk in the PRIMET model.

\section{PRIMET input parameters}

\section{Pesticide characteristics}

The pesticide characteristics required for the PRIMET model are listed in Table 1. The pesticide products and active ingredients evaluated are the most used pesticides on maize, wheat, lucerne and groundnuts within the VHIS. The variables in Table 1 were either readily available in open scientific literature sources due to their widespread use or already given in the PRIMET database. The relevant EC50 data were extracted from the USEPA AQUIRE (USEPA, 2009), PAN (2009), EXTOXNET (2009) and PPDB (IUPAC, 2010) toxicity databases. Peer-reviewed literature and The Pesticide Manual (Tomlin, 2000) were also used for certain values. The toxicity data extracted from these databases were for the acute static tests for freshwater invertebrates $(48 \mathrm{~h})$, vertebrates $(96 \mathrm{~h})$ and primary producers ( $72 \mathrm{~h}$ and $96 \mathrm{~h}$ ). If more than one value was obtained, a mean toxicity value was used in the model. The toxicity data used in the PRIMET model is presented in Table 2. 
TABLE 1

Selected pesticide products used within the VHIS, their active ingredients and physico-chemical properties

\begin{tabular}{|c|c|c|c|c|c|c|c|c|c|c|}
\hline Pesticide Product & \begin{tabular}{|l} 
Active \\
Ingredient
\end{tabular} & $\begin{array}{l}\text { Pesticide } \\
\text { type }\end{array}$ & $\begin{array}{c}\text { Molecular } \\
\text { mass }\end{array}$ & $\begin{array}{c}\text { Saturated } \\
\text { vapour } \\
\text { Pressure } \\
(\mathrm{Pa})\end{array}$ & $\begin{array}{l}\text { Tempera- } \\
\text { ture } \\
\text { saturated } \\
\text { vapour } \\
\text { pressure } \\
\left({ }^{\circ} \mathrm{C}\right) \\
\end{array}$ & $\begin{array}{l}\text { Solubility } \\
\text { (mg/e) }\end{array}$ & \begin{tabular}{|c|} 
Tempera- \\
ture \\
solubility \\
$\left({ }^{\circ} \mathrm{C}\right)$
\end{tabular} & \begin{tabular}{|c}
$\mathrm{DT}_{50} /$ \\
Halflife- \\
water \\
(days)
\end{tabular} & \begin{tabular}{|c|}
$\mathrm{DT}_{50^{-}}$ \\
sediment \\
(days)
\end{tabular} & $\begin{array}{c}\mathrm{K}_{\mathrm{om}} \\
(\ell / \mathrm{kg})\end{array}$ \\
\hline 'Temik ${ }^{\mathrm{TM}}$ ' & Aldicarb & $\begin{array}{l}\text { Insecticide, } \\
\text { Nematicide }\end{array}$ & 190.3 & 6.608 & 20 & 4980 & 20 & 10 & 6.09 & 28.5 \\
\hline 'Guardian' & Acetochlor & Herbicide & 269.8 & 400 & 20 & 223 & 20 & 154 & 14 & 117.7 \\
\hline 'Harness ${ }^{\mathrm{TM}}$ ' & Acetochlor & Herbicide & 269.8 & 400 & 20 & 223 & 20 & 154 & 14 & 117.7 \\
\hline 'Terbuzin ${ }^{\mathrm{TM}}$ ' & Atrazine & Herbicide & 215.7 & 0.01909 & 20 & 32.62 & 20 & 81 & 77.88 & 73.3 \\
\hline 'Atrazine $500 \mathrm{SC}^{\mathrm{TM}}$ ' & Atrazine & Herbicide & 215.7 & 0.01909 & 20 & 32.62 & 20 & 81 & 77.88 & 73.3 \\
\hline 'Basagran ${ }^{\mathrm{TM}}$ ' & $\begin{array}{l}\text { Bendioxide / } \\
\text { Bentazone }\end{array}$ & Herbicide & 240.3 & 0.17 & 20 & 520 & 20 & 1 & 67.37 & 11.17 \\
\hline 'Buctril ${ }^{\mathrm{TM}}$ ' & Bromoxynil & Herbicide & 276.9 & 0.08827 & 20 & 74.7 & 20 & 5 & 1.458 & 103.7 \\
\hline 'Punch ${ }^{\mathrm{TM}}$ ' & Carbendazim & Fungicide & 191.2 & 0.09 & 20 & 15.5 & 20 & 0.2 & 0.065 & 144.8 \\
\hline 'Folicur ${ }^{\mathrm{TM}}$ ' & Carbendazim & Fungicide & 191.2 & 0.09 & 20 & 15.5 & 20 & 0.2 & 0.065 & 144.8 \\
\hline 'Decis ${ }^{\mathrm{TM}}$ ' & Deltamethrin & Insecticide & 505.2 & $1.5 \mathrm{E}-8$ & 20 & 0.001083 & 20 & 2 & 25.88 & 276 \\
\hline 'Metasystox ${ }^{\mathrm{TM}}$ ' & $\begin{array}{l}\text { Oxydemeton- } \\
\text { methyl }\end{array}$ & Insecticide & 246.3 & 0.04 & 20 & 1200000 & 20 & 3 & 6 & 17.4 \\
\hline 'Dimetoaat ${ }^{\mathrm{TM}}$ ' & Dimethoate & Insecticide & 229.3 & 0.29 & 20 & $2.5 \mathrm{E} 4$ & 20 & 32.49 & 4.886 & 1528 \\
\hline 'Punch ${ }^{\mathrm{TM}}$ ' & Flusilazole & Fungicide & 315.4 & 14.6 & 20 & 54 & 20 & 1 & 420 & 965.2 \\
\hline 'Roundup ${ }^{\mathrm{TM}}$ ' & Glyphosate & Herbicide & 169.1 & 0.006802 & 20 & 10.2 & 20 & 3.6 & 17.63 & 6.09 \\
\hline 'Servian ${ }^{\mathrm{TM}}$ ' & Halosulfuron & Herbicide & 434.8 & 0.00001 & 25 & 1650 & 20 & 14 & 14 & 66.71 \\
\hline 'Hammer ${ }^{\mathrm{TM}}$ ' & Imazetapyr & Herbicide & 289.3 & 0.013 & 20 & 1.4 & 20 & 30 & 51 & 30.16 \\
\hline 'Gramoxone ${ }^{\mathrm{TM}}$ ' & Paraquat & Herbicide & 257.2 & $1 \mathrm{E}-5$ & 20 & 620 & 20 & 10000 & 3000 & $5.8 \mathrm{E} 5$ \\
\hline 'Parathion ${ }^{\mathrm{TM}}$ ' & Parathion & Insecticide & 291.3 & 5 & 20 & 19.92 & 20 & 1.5 & 6 & 1764 \\
\hline 'Folicur ${ }^{\mathrm{TM}}$ ' & Tebuconazole & Fungicide & 307.8 & 1.733 E-6 & 20 & 36 & 20 & 43 & 516.3 & 610.5 \\
\hline 'Terbuzin ${ }^{\mathrm{TM}}$ ' & Terbuthylazine & Herbicide & 229.7 & 0.04673 & 20 & 9 & 20 & 6 & 31 & 127 \\
\hline 'Treflan ${ }^{\mathrm{TM}}$ ' & Trifluralin & Herbicide & 335.3 & 0.0265 & 20 & 24 & 20 & 8.9 & 60 & 4060 \\
\hline
\end{tabular}

\section{Application scheme}

The PRIMET model requires data on the number of applications, the individual dosage/concentration and the time interval between applications of the various pesticides. The required data were generated with the situation analysis by interviewing the farmers and pesticide consultants. Various labels and material safety data sheets (MSDS) of the pesticides were also valuable to determine the concentrations of the active ingredients in the various pesticide products. The percentage spray drift (\% drift) was calculated using the IMAG Drift Calculator v1.1 (Holterman and Van der Zande, 2003). The estimated drift when using conventional spraying equipment was calculated using a simple first-tier assessment.

\section{Physical scenario of aquatic environment}

There are various physical scenarios for the aquatic environment present within the VHIS as there are approximately 1000 $\mathrm{km}$ of canals in the area. The majority of these canals bring water into secondary canals and dams before it is used for irrigation. The run-off and leachate from the pastures are captured within drainage canals and returned to the Harts River. These numerous drainage canals present in the scheme potentially transport pesticides directly into the Harts River.

One section of the drainage canal system was selected for the implementation of the PRIMET model. The physical parameters in Table 3 for the scenario were determined during the 2008 sampling survey through the use of tape measures and water samples. Active spraying programmes would have been on-going during this period of determining the scenario for the PRIMET model. The mass fraction of organic matter was determined using the method of Wepener and Vermeulen (2005). The parameters measured included side slope, flow velocity, bottom width, depth and length of canal, organic matter, and ambient temperature in the scenario.

The VHIS receives its water from the Vaalharts Weir on the Vaal River from where the water is moved into two main canals leading to the irrigation scheme (Fig. 1). Water hyacinth, in particular, is a problem within the weir. Secondary canals then transport water to the individual farms and their respective irrigation dams from where irrigation takes place. The allocation is done weekly with a specific Water Allocation System (WAS, Jansen van Vuuren et al., 2004). The irrigation scheme runs year round with only a couple of weeks set aside for maintenance each year. 


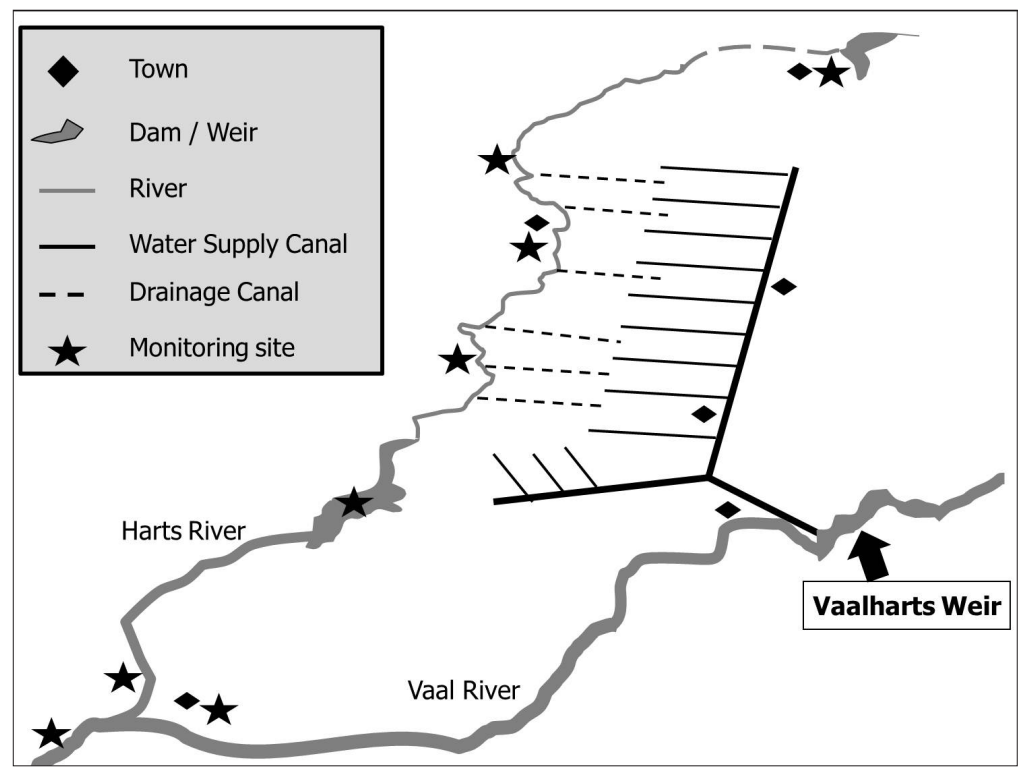

Figure 1

Schematic diagram of the VHIS on the Harts and Vaal Rivers.

The various canal structures and sources of water are indicated on the schematic diagram.
The farmers then irrigate their crops using various irrigation techniques that include flood, centre-pivot and microirrigation. The water passes through the soil into the various drainage pipes that are installed in the majority of farms. These pipes then take the water into larger canals running parallel to the fields. The canals merge into various larger canals. At certain places these canals are affected by sedimentation and algae due to the increased nutrients in the water. Drainage canals are only lined with cement until a few hundred meters from the confluence with the Harts River, thereafter the canal becomes a ditch. This leads to extreme erosion of the ditch and an increase in sedimentation in the downstream sections of the Harts River.

\section{RESULTS AND DISCUSSION}

\section{The PRIMET model application}

The aquatic risk assessment was undertaken using the application rates and toxicity values given in Tables 1 and 2. The ETR

TABLE 2

Acute toxicity data for the selected pesticide active ingredients used in the PRIMET model for vertebrates ( $96 \mathrm{~h})$, invertebrates $(48 \mathrm{~h})$ and primary producers $(96 \mathrm{~h})$

\begin{tabular}{|c|c|c|c|c|c|}
\hline Active ingredient & $\begin{array}{c}\text { Vertebrates } \mathrm{L}(\mathrm{E}) \mathrm{C}_{50} \\
(\mathrm{mg} / \mathrm{l})\end{array}$ & $\begin{array}{c}\text { Invertebrates } \mathrm{L}(\mathrm{E}) \mathrm{C}_{50} \\
(\mathrm{mg} / \mathrm{l})\end{array}$ & $\begin{array}{l}\text { Primary producers } \\
\mathrm{L}(\mathrm{E}) \mathrm{C}_{50}(\mathrm{mg} / \mathrm{\ell})\end{array}$ & NOEC Fish & NOEC Daphnia \\
\hline Aldicarb & 0.4224 & 0.411 & 50 & 0.078 & 0.411 \\
\hline Acetochlor & 0.36 & 9 & 4.3 & 0.45 & 0.0427 \\
\hline Atrazine & 24.45 & 5.29 & 0.06 & 0.06 & 0.04 \\
\hline Bendioxide/Bentazon & 64 & 1137 & 58.15 & 48 & 120 \\
\hline Bromoxynil & 12.19 & 0.0735 & 0.8836 & 2 & 3.1 \\
\hline Carbendazim & 1.301 & 0.2615 & 7.9 & 0.008406 & 1.239 \\
\hline Deltamethrin & 0.0075 & 0.0002 & 9100 & 0.0005 & 0.001247 \\
\hline Oxydemeton-methyl & 28.2 & 1.41 & 49 & 1.8 & 0.027 \\
\hline Dimethoate & 30 & 4.7 & 300 & 0.1 & 0.032 \\
\hline Flusilazole & 1.2 & 3.4 & 6.4 & 0.23 & 1.8 \\
\hline Glyphosate & 38 & 41.86 & 0.64 & 25 & 21.68 \\
\hline Halosulfuron & 131 & 107 & 0.0053 & - & - \\
\hline Imazetapyr & 340 & 1000 & 50 & 97 & 1000 \\
\hline Paraquat & 19 & 4.4 & 0.00023 & - & 0.12 \\
\hline Parathion & 1.5 & 0.0025 & 0.5 & 0.00072 & 0.0001 \\
\hline Tebuconazole & 4.3 & 4.2 & 3.064 & 0.012 & 0.13 \\
\hline Terbuthylazine & 3.541 & 21.2 & 0.012 & 0.045 & 0.019 \\
\hline Trifluralin & 3.5 & 0.28 & 9.14 & 0.002 & 0.051 \\
\hline
\end{tabular}




\begin{tabular}{|c|c|}
\hline \multicolumn{2}{|c|}{$\begin{array}{l}\text { TABLE } 3 \\
\text { Physical parameters of the VHIS scenario for use within the } \\
\text { PRIMET model }\end{array}$} \\
\hline Parameter & Scenario \\
\hline Bottom width of water body $(\mathrm{m})$ & 2 \\
\hline Depth of water body $(\mathrm{m})$ & 0.1 \\
\hline Length of water body $(\mathrm{m})$ & 10000 \\
\hline $\begin{array}{l}\text { Mass fraction organic matter in suspended solids } \\
(\mathrm{g} / \mathrm{g})\end{array}$ & 0.499 \\
\hline $\begin{array}{l}\text { Mass concentration of suspended solids in water } \\
(\mathrm{kg} / \ell)\end{array}$ & $1.027 \mathrm{E}-5$ \\
\hline Ambient temperature in scenario $\left({ }^{\circ} \mathrm{C}\right)$ & 25 \\
\hline Side slope & 10 \\
\hline Flow velocity $(\mathrm{m} / \mathrm{d})$ & 40000 \\
\hline
\end{tabular}

results are presented in Table 4 and include the application scheme, PEC and PNEC values for each pesticide-crop combination. The ETR was classified into 3 categories: 'no risk' (ETR $<1)$, 'possible risk' $(\mathrm{ETR}<100)$ and 'definite risk'

$($ ETR $>100)$. These results are based on a worst-case scenario.

\section{The 'no risk' category}

The calculated ETRs of the following pesticides indicated 'no risk': atrazine $(\mathrm{ETR}=0.5$; ETR $=0.9)$; bendioxide/bentazone $(\mathrm{ETR}=0.04)$; carbendazim $(\mathrm{ETR}=0.2$; ETR $=0.5)$; oxydemeton-methyl $(\mathrm{ETR}=0.2)$; dimethoate $(\mathrm{ETR}=0.01)$; flusilazole $(\mathrm{ETR}=0.1)$; glyphosate $(\mathrm{ETR}=0.2)$; halosulfuron $(\mathrm{ETR}=0.9)$; imazethapyr $(\mathrm{ETR}=0.0001)$; and tebucanazole $(\mathrm{ETR}=0.04)$. Atrazine is found in two pesticide formulations: 'Atrazine 500 $\mathrm{SC}^{\mathrm{m} \mathrm{s}}$, and in combination with terbuthylazine in 'Terbuzin ${ }^{\mathrm{Tm}}$. It is used as a pre- and post-emergence herbicide. It can persist in the aquatic ecosystem for up to 6 months but studies have shown it to be only slightly toxic to aquatic organisms with a low tendency to bio-concentrate (ATSDR, 2003). The slight toxicity of atrazine is very dependent on the exposed concentration and the endpoints that are measured. Bendioxide (or bentazone) is used as a post-emergence herbicide of groundnuts. The low toxicity of bentazone to aquatic organisms is possibly due to its higher degradability and as such poses a low risk to the aquatic ecosystem. This pesticide was also included in the Crocodile River (West) Irrigation Scheme study (Ansara-Ross et al., 2008), which similarly indicated a low risk to the aquatic ecosystem $($ ETR $=0.04)$.

The fungicides 'Punch $\mathrm{C}^{\mathrm{mm} \text { ' }}$ and 'Folicur ${ }^{\mathrm{Tm}}$, with the active ingredient carbendazim, are usually only applied once per season to prevent fungi. In some instances a second dose might be needed should fungi remain. The low dosage and single application of this pesticide ensured that it did not pose a risk to the aquatic environment. Flusilazole (a triazole), is a fungicide that forms part of the pesticide 'Punch $\mathrm{C}^{\mathrm{TM}}$ ', which also contains carbendazim. Flusilazole has shown toxicity to aquatic organisms according to pesticide databases (PPDB; IUPAC, 2010), but the low application rates within the VHIS ensures it poses no risk to the aquatic environment. 'Folicur ${ }^{\mathrm{TM}}$ ' also contains the active ingredient tebuconazole. Tebuconazole posed no risk to the aquatic environment according to the PRIMET prediction. Literature indicated that data are scarce for this pesticide but the few studies available did show moderate toxicity to fish and invertebrates (PAN, 2009; IUPAC, 2010).

Oxydemeton-methyl and dimethoate are organophosphate pesticides used as an insecticide to control outbreaks and occurrences of aphids on wheat and lucerne during the winter months. They act by inhibiting acetylcholine esterase (IUPAC, 2010) and, according to PAN (2009), are highly toxic to insects and less toxic to fish. In most cases these pesticides are only applied once during a season to eliminate these pests. The onceoff application and fairly low dosage resulted in no risk being predicted for these pesticides using the PRIMET model. The pesticide product 'Roundup ${ }^{\mathrm{TM}}$ ' contains the active ingredient glyphosate and is used as a broad-spectrum herbicide to control various perennial grasses and weeds. It is used on many different crops but generally only two applications are necessary. According to the literature, glyphosate is only slightly toxic to aquatic organisms (PAN, 2009) and thus should pose no risk to the aquatic environment. Another herbicide used is halosulfuron for the control of weeds associated with maize. The application rates are low and, together with the low to moderate toxicity noted in the literature, there was no risk predicted. However, no NOEC data were available (PAN, 2009; IUPAC, 2010), so the ETR of halosulfuron should be considered with a lower confidence. If additional data becomes available it will potentially change the ETR. The pesticide ' $\mathrm{Hammer}^{\mathrm{TM}}$ ', with the active ingredient imazethapyr, posed no risk to the aquatic environment due to its low toxicity towards fish and invertebrates (PAN, 2009). Imazethapyr is an imidazolinone herbicide that provides systemic and residual control of various weeds.

\section{The 'possible risk' category}

The PRIMET model predicted a 'possible risk' ETR category (Table 4) for aldicarb (ETR $=4.9$ ), acetochlor (used on groundnuts; ETR = 4.5; used on maize; ETR = 4.3), deltamethrin (used on lucerne and maize; ETR = 49.9), bromoxynil (6.1), terbuthylazine $(\mathrm{ETR}=2.4)$ and trifluralin $(\mathrm{ETR}=15.3)$.

The herbicide 'Harness ${ }^{\mathrm{TM}}$ ' with the active ingredient acetochlor was predicted to pose a possible risk to the aquatic environment. Acetochlor is a chloroacetamide that is widely used to control broad-leafed weeds and annual grasses, postplant but pre-emergence. It is applied once per season for groundnuts but the high concentration (1 $223 \mathrm{~g}$ a.i./ha) coupled with its moderate toxicity (PAN, 2009) contributes to the possible risk to the aquatic environment. Acetochlor is also used in the pesticide product, 'Guardian ${ }^{\mathrm{Tm}}$, , for pre-planting control of various weeds associated with maize. Acetochlor is mainly absorbed by the roots and leaves (Nemeth-Konda et al., 2002) and acts by inhibiting and disturbing electron transport during photosynthesis (Huang and Xiong, 2009). The PEC for acetochlor was predicted to be $16.3 \mu \mathrm{g} / \ell$ which is lower than the $\mathrm{L}(\mathrm{E}) \mathrm{C} 50$ values for vertebrates, invertebrates and primary producers, as presented in Table 2. However, very few toxicity studies have been completed on acetochlor (Relyea, 2009)) and some studies did indicate effects on cladocerans from 6-16 $\mu \mathrm{g} / \ell$ (Kashian and Dodson, 2002). Kashian and Dodson (2002) did indicate that listed EC50 concentrations for Daphnia for certain pesticides could be inaccurate as they found environmentally relevant effects at lower concentrations. Relyea (2009) found that acetochlor decreases phytoplankton, as a separate active ingredient as well as in a mixture of herbicides. This decrease in phytoplankton was attributed to the direct toxicity of acetochlor on phytoplankton.

Terbuthylazine is a herbicide that, together with atrazine, is an active ingredient in 'Terbuzine ${ }^{\mathrm{TM}}$ ', a pesticide used to control mainly broad-leafed weeds in maize (Dolaptsoglou et al., 2007). Terbuthylazine is a triazine pesticide that is moderately toxic to fish and highly toxic to zooplankton (PAN, 2009). Literature 


\begin{tabular}{|c|c|c|c|c|c|c|c|c|c|c|}
\hline $\begin{array}{l}\text { Selected pesticide } \\
\text { and the recomm } \\
\text { applications (PE }\end{array}$ & $\begin{array}{l}\text { es used in the VHIS and } \\
\text { mended application dos } \\
\text { EC n) together with the }\end{array}$ & $\begin{array}{l}\text { their relevant } \\
\text { sage. The prec } \\
\text { predicted no e } \\
\text { deriv }\end{array}$ & $\begin{array}{r}\text { TABLE } \\
\text { pplicatio } \\
\text { cted effe } \\
\text { fect conc } \\
\text { d from th }\end{array}$ & $\begin{array}{l}\text { E } 4 \\
\text { on rates, as d } \\
\text { cts concentr } \\
\text { centrations ( } P \\
\text { hese values. }\end{array}$ & $\begin{array}{l}\text { letermine } \\
\text { ations fo } \\
\text { PNEC) are }\end{array}$ & $\begin{array}{l}\text { ed from q } \\
\text { one app } \\
\text { also sup }\end{array}$ & $\begin{array}{l}\text { uestion } \\
\text { lication } \\
\text { plied. }\end{array}$ & $\begin{array}{l}\text { laire sur } \\
\text { (PEC 1) } \\
\text { he resul }\end{array}$ & $\begin{array}{l}\text { vey of } f \\
\text { and mul } \\
\text { ting ETR }\end{array}$ & $\begin{array}{l}\text { armers } \\
\text { Itiple } \\
\text { R was }\end{array}$ \\
\hline Pesticide product & Active ingredient & Crop & \begin{tabular}{|c|} 
Appli- \\
cation \\
Interval \\
(days)
\end{tabular} & \begin{tabular}{|c|} 
Applied / \\
Recommen- \\
ded dose \\
(g a.i./ha) \\
\end{tabular} & \begin{tabular}{|c|}
$\begin{array}{l}\text { Number } \\
\text { of appli- } \\
\text { cations }\end{array}$ \\
\end{tabular} & \begin{tabular}{|c|} 
Spray \\
drift (\%)
\end{tabular} & $\begin{array}{l}\text { PEC 1 } \\
\text { water } \\
(\mu \mathrm{g} / \ell)\end{array}$ & $\begin{array}{l}\text { PEC } n \\
\text { water } \\
(\mu \mathrm{g} / \ell)\end{array}$ & $\begin{array}{l}\text { PNEC } \\
\text { water }\end{array}$ & \begin{tabular}{|c} 
ETR (PEC/ \\
PNEC)
\end{tabular} \\
\hline 'Temik ${ }^{\mathrm{TM}}$ ' & Aldicarb & $\begin{array}{l}\text { Groundnuts, } \\
\text { maize and } \\
\text { cotton }\end{array}$ & 180 & 1500 & 2 & 1 & 20 & 20 & 4.1 & 4.9 \\
\hline 'Harness ${ }^{\mathrm{TM}}$ & Acetochlor & Groundnuts & 365 & 1223 & 1 & 1 & 16.3 & 16.3 & 3.6 & 4.5 \\
\hline 'Guardian' ${ }^{\mathrm{TM}}$ ' & Acetochlor & Maize & 365 & 216 & 1 & 1 & 15.35 & 15.35 & 3.6 & 4.3 \\
\hline 'Terbuzin ${ }^{\mathrm{TM}}$ ' & Atrazine & Maize & 365 & 216 & 1 & 1 & 2.9 & 2.9 & 6 & 0.5 \\
\hline 'Atrazine $500 \mathrm{SC}^{\mathrm{TM}}$ ' & Atrazine & Maize & 365 & 400 & 1 & 1 & 5.3 & 5.3 & 6 & 0.9 \\
\hline 'Basagran ${ }^{\mathrm{TM}}$ ' & \begin{tabular}{|l|} 
Bendioxide / \\
Bentazone
\end{tabular} & Groundnuts & 365 & 1920 & 1 & 1 & 25.6 & 25.6 & 640 & 0.04 \\
\hline 'Buctril ${ }^{\mathrm{TM}}$ ' & Bromoxynil & Wheat & 3 & 337.5 & 2 & 1 & 4.5 & 4.5 & 0.7 & 6.1 \\
\hline 'Punch C C' & Carbendazim & Groundnuts & 365 & 43.75 & 1 & 1 & 0.6 & 0.6 & 2.6 & 0.2 \\
\hline 'Folicur ${ }^{\mathrm{TM}}$ ' & Carbendazim & Groundnuts & 365 & 93.1 & 1 & 1 & 1.2 & 1.2 & 2.6 & 0.5 \\
\hline 'Decis ${ }^{\mathrm{TM}}$ ' & Deltamethrin & Cotton & 365 & 31.25 & 1 & 1 & 0.4 & 0.4 & 0.002 & 208 \\
\hline 'Decis ${ }^{\mathrm{TM}}$ & Deltamethrin & \begin{tabular}{|l}
$\begin{array}{l}\text { Lucerne, } \\
\text { Maize }\end{array}$ \\
\end{tabular} & 365 & 7.5 & 1 & 1 & 0.1 & 0.1 & 0.002 & 49.9 \\
\hline 'Metasystox ${ }^{\mathrm{TM}}$ ' & Oxydemeton - methyl & Wheat & 365 & 162.5 & 1 & 1 & 2.2 & 2.2 & 14.1 & 0.2 \\
\hline 'Dimetoaat ${ }^{\mathrm{TM}}$ ' & Dimethoate & Lucerne & 365 & 42 & 1 & 1 & 0.6 & 0.6 & 47 & 0.01 \\
\hline 'Punch C C ${ }^{\mathrm{TM}}$ ' & Flusilazole & Groundnuts & 365 & 87.5 & 1 & 1 & 1.2 & 1.2 & 12 & 0.1 \\
\hline 'Roundup ${ }^{\mathrm{TM}}$ ' & Glyphosate & General & 20 & 850 & 2 & 1 & 11.3 & 11.3 & 64 & 0.2 \\
\hline 'Servian ${ }^{\mathrm{TM}}$ ' & Halosulfuron & Maize & 365 & 37.5 & 1 & 1 & 0.5 & 0.5 & 0.5 & 0.9 \\
\hline 'Hammer' & Imazetapyr & Groundnuts & 365 & 30 & 1 & 1 & 0.4 & 0.4 & 3400 & 0.0001 \\
\hline 'Gramoxone ${ }^{\mathrm{TM}}$ ' & Paraquat & General & 24 & 500 & 2 & 1 & 1.7 & 1.7 & 0.02 & 73 \\
\hline 'Parathion ${ }^{\mathrm{TM}}$ ' & Parathion & Wheat & 365 & 325 & 1 & 1 & 4.3 & 4.3 & 0.03 & 171.8 \\
\hline 'Folicur ${ }^{\mathrm{TM}}$ ' & Tebuconazole & Groundnuts & 365 & 116.9 & 1 & 1 & 1.6 & 1.6 & 42 & 0.04 \\
\hline 'Terbuzin ${ }^{\mathrm{TM}}$ ' & Terbuthylazine & Maize & 365 & 216 & 1 & 1 & 2.9 & 2.9 & 1.2 & 2.4 \\
\hline 'Treflan ${ }^{\mathrm{TM}}$ & Trifluralin & Cotton & 365 & 480 & 1 & 1 & 6.3 & 6.3 & 0.4 & 15.3 \\
\hline
\end{tabular}

reports a wide range of EC50 for the different trophic levels in aquatic ecosystems, with algae being the most sensitive group, and for that reason terbuthylazine is also used as an algicide in some parts of the world (Coors et al., 2006). Even though terbuthylazine is generally only applied once per season, the predicted effect concentration of $2.9 \mu \mathrm{g} / \ell$ poses a risk to the environment. The reason for this is the toxicity towards algae and macrophytes rather than the toxicity towards fish and invertebrates (Table 2).

Trifluralin is a dinitroaniline pesticide that is used to control annual grasses and broad-leafed weeds in various crops. It acts by inhibiting mitosis and cell division before the weeds emerge (EXTOXNET, 2009; IUPAC, 2010). Literature (USEPA, 1996; PAN, 2009) indicates that trifluralin is highly toxic to fish while it shows moderate toxicity to invertebrates. Trifluralin can also be persistent and has the potential to bioaccumulate (USEPA, 1999). The PEC of $6.3 \mu \mathrm{g} / \ell$ is lower than the LC50 and NOEC50 for invertebrates, but it is higher than the NOEC50 of fish. It is most likely that the predicted risk is due to the high toxicity of trifluralin towards fish.

Aldicarb, a carbamate pesticide, is a systemic insecticide and nematicide used to control insect pests of groundnuts, maize and cotton (EXTOXNET, 2009). It is generally applied twice per season to control pests and, together with the high dose (Table 3.4), it results in a possible risk being predicted. Aldicarb is highly toxic to aquatic organisms (PAN, 2009) but bioaccumulation potential of the pesticide is low due to its high solubility in water (Ansara-Ross et al., 2008). Canadian Water Quality Guidelines for the protection of aquatic life give a limit of $1 \mu \mathrm{g} / \ell$ for aldicarb (PAN, 2009), which is significantly lower than the $20 \mu \mathrm{g} / \ell$ PEC determined by PRIMET. Thus potential risk to the aquatic ecosystem is possible.

Bromoxynil is a herbicide used mainly on wheat in the VHIS in order to control broad-leafed weeds. It is a nitrile pesticide (hydroxybenzonitrile) that inhibits photosynthesis by acting upon photosystem II (EXTOXNET, 2009; IUPAC, 2010). 
Literature (PAN, 2009) indicates that it is highly toxic to zooplankton but only slightly toxic to fish. Canadian Water Quality Guidelines for bromoxynil are set at $5 \mu \mathrm{g} / \ell$ which is similar to the $4.5 \mu \mathrm{g} / \ell$ PEC predicted for one application. However, the pesticide is often applied twice within 3 days to ensure adequate control and the PEC of 2 applications can reach $7.8 \mu \mathrm{g} / \ell$; however, it is dependent on the flow conditions within the drainage canals. On average the flow rate in the canals is around $40 \mathrm{~km} /$ day, which will ensure that the bromoxynil concentration does not exceed $4.5 \mu \mathrm{g} / \ell$, but if the flow velocities are lower the concentration could increase. The application of bromoxynil therefore poses a possible risk of affecting the aquatic ecosystem. Where possible, the use of bromoxynil should be restricted to a once-off application as this will reduce the risk to the aquatic ecosystem.

Deltamethrin, as applied to lucerne and maize, posed a possible risk to the environment, but its application to cotton indicated a definite risk. Therefore, it will be discussed further under the «definite risk category.

\section{The 'definite risk' category}

The application of the PRIMET model indicated 3 pesticides posing a 'definite risk' to the aquatic ecosystem. These pesticides were deltamethrin (used on cotton; ETR $=208$ ), paraquat $($ ETR $=73)$ and parathion $($ ETR $=172)$. Of these three pesticides, deltamethrin and parathion were also previously predicted to pose definite risks in the Crocodile (West) Irrigation scheme (Ansara-Ross et al., 2008), though the risk calculated was lower (possible risk) than that found in the present study. The use of deltamethrin indicated an ETR of 75 in the Crocodile (West) irrigation scheme as compared to the ETR of 208 for cotton and ETR of 49.9 for use on lucerne and maize. The differences between ETR for cotton and the ETR for lucerne and maize are attributed to the differing application rates, time interval between applications and application concentrations.

Deltamethrin is a synthetic pyrethroid insecticide that is highly toxic to fish under laboratory conditions. However, its toxicity decreases significantly under natural in-field conditions as it undergoes microbial degradation, and also due to its good adsorptive properties (Schroer et al., 2004). Intensive application of deltamethrin causes toxicity to aquatic arthropods as well (Solomon et al., 2001). Deltamethrin is hydrophobic and has a high octanol-water coefficient which indicates a potential to bio-concentrate within aquatic organisms. The bio-concentration of this pesticide can potentially cause toxicity to aquatic invertebrates and fish (Van der Werf, 1996; Solomon et al., 2001).

The PRIMET model PEC concentrations for the two application scenarios of deltamethrin were 0.1 (lucerne, maize) and 0.42 (cotton) $\mu \mathrm{g} / \ell$. These values are higher than the L(E)C50 values reported in Table 2 for vertebrates, invertebrates and primary producers. The limit given by the Canadian Water Quality Guidelines for the protection of aquatic life is also set significantly lower at $0.0004 \mu \mathrm{g} / \ell$. Therefore the probability of risks to the aquatic ecosystem is definite even at the low application concentrations of $7.5 \mathrm{~g}$ a.i/ha (lucerne, maize) and 31.25 g a.i/ha (cotton).

Parathion is an organophosphate insecticide used to control various sucking and biting insects as well as mites (IUPAC, 2010). It is mainly used on wheat during the winter months for the control of lice. Parathion has a moderate toxicity to fish but a high toxicity to most aquatic invertebrates (EXTOXNET, 2009). However, it has low mobility based on $K_{o c}$ values and leaching studies. Parathion also degrades rapidly under laboratory and field conditions (Tomlin, 2000). The PEC of $4.3 \mu \mathrm{g} / \ell$ is higher than the $\mathrm{L}(\mathrm{E}) \mathrm{C} 50$ literature values for vertebrates, invertebrates and primary producers (Table 2). Parathion was also identified by Ansara-Ross et al. (2008) as a pesticide with definite risk in the Crocodile (West) River. The ETR of 20 was much lower compared to the value of 170 in this study.

The broad-spectrum herbicide paraquat is included in the pesticide product 'Gramoxone ${ }^{\mathrm{TM}}$ ' (IUPAC, 2010). This product is used in varying quantities on various crops for a range of weeds, but for the purpose of the prediction a specified application quantity was used, as indicated on the label. On average paraquat is only slightly/moderately toxic to aquatic organisms (PAN, 2009) and is highly persistent in soils (EXTOXNET, 2009). The PEC of $1.7 \mu \mathrm{g} / \ell$ is lower than the literature $\mathrm{L}(\mathrm{E}) \mathrm{C} 50$ values for vertebrates and invertebrates but it is significantly higher than the EC50 value for primary producers (Table 2).

\section{PERPEST model results}

The PERPEST model was applied to pesticides for which a 'possible' or 'definite' risk was indicated in the first-tier risk assessment using the PRIMET model. The PEC value generated with the PRIMET model was used as an input parameter into the PERPEST model together with basic physical characteristics of the pesticide. The PERPEST results were in the form of percentage probabilities for effects to occur in 8 grouped endpoints. The probabilities generated with PERPEST are presented in Table 5 for the insecticides and Table 6 for the herbicides. The insecticide PERPEST results indicated very high probabilities $(>71 \%)$ of clear effects occurring on insects and macro- and micro-crustaceans due to the use of deltamethrin and parathion. These results were expected due to the high ETR ratios predicted by PRIMET. However, aldicarb also indicated similarly high probabilities of effects occurring even though the aldicarb ETR was lower than for deltamethrin and parathion. The ETR generated with PRIMET cannot be compared between chemicals as effects above threshold concentrations for specific chemicals are not linearly correlated with the concentrations, i.e., an ETR of 200 compared to an ETR of 100 does not necessarily indicate double the risk. Other insects and rotifer endpoints indicated a much lower probability (around 30\%) of clear effects occurring for these insecticides. High probabilities $(80-90 \%)$ of no effects occurring on fish and community metabolism were predicted for these insecticides. The PERPEST prediction for aldicarb in the Crocodile (West) Marico study (Ansara-Ross et al., 2008) yielded high probabilities of no effects occurring on all aquatic communities. Their results for parathion indicated only a $27 \%$ probability of clear effects occurring on aquatic insects as compared to this study which indicated an $82 \%$ probability. However, this is a result of the different PEC values predicted within the PRIMET model and not differences in the implementation of the PERPEST model. Results for deltamethrin indicated a $100 \%$ probability of clear effects occurring on insects and macro-crustaceans at a PEC of $0.04 \mu \mathrm{g} / \ell$ (Ansara-Ross et al., 2008).

The level of exposure to the herbicides paraquat, terbuthylazine and trifluralin did not result in any high probabilities of effects occurring for community metabolism, macrophytes, fish and tadpoles, macro-crustaceans and insects, molluscs, periphyton, phytoplankton and zooplankton effect classes (Table 6). The prediction for acetochlor using the PRIMET model indicated possible risks. The PERPEST model however predicted very high probabilities (> 75\%) of clear effects 
TABLE 5

The percentage probability (Prob) of effect classes (No Effect, Slight Effect and Clear Effect) for 8 grouped ecological endpoints with the respective lower $(5 \% \mathrm{CL})$ and upper $(95 \% \mathrm{CL})$ confidence interval for each of the insecticides calculated using PERPEST ( $n=$ number of studies used in the analysis)

\begin{tabular}{|c|c|c|c|c|c|c|c|c|c|c|c|c|}
\hline \multirow[t]{2}{*}{ Insecticides } & \multicolumn{3}{|c|}{ Aldicarb $(20 \mu \mathrm{g} / \ell)$} & \multicolumn{3}{|c|}{ Deltamethrin $(0.4 \mu \mathrm{g} / \ell)$} & \multicolumn{3}{|c|}{ Deltamethrin $(0.1 \mu \mathrm{g} / \ell)$} & \multicolumn{3}{|c|}{ Parathion $(4.3 \mu \mathrm{g} / \ell)$} \\
\hline & Prob & $5 \% \quad C L$ & $95 \% \mathrm{CL}$ & Prob & $5 \% \quad \mathrm{CL}$ & $95 \% \mathrm{CL}$ & Prob & $5 \% \quad \mathrm{CL}$ & $95 \% \mathrm{CL}$ & Prob & $5 \% \quad \mathrm{CL}$ & $95 \% \mathrm{CL}$ \\
\hline Algae and macrophytes & \multicolumn{3}{|c|}{$n=52$} & \multicolumn{3}{|c|}{$n=48$} & \multicolumn{3}{|c|}{$n=52$} & \multicolumn{3}{|c|}{$n=52$} \\
\hline Probability of no effect & 56.4 & 42.9 & 73.4 & 51.7 & 34.3 & 65.4 & 75.3 & 60.7 & 85.6 & 68.3 & 59.4 & 83.5 \\
\hline Probability of slight effect & 8.6 & 2.8 & 16 & 13.2 & 3.7 & 29.5 & 9.9 & 2.6 & 19 & 9.1 & 2.2 & 16.1 \\
\hline Probability of clear effect & 35 & 17.9 & 48.5 & 35.1 & 21.3 & 48.5 & 14.8 & 6.6 & 28.3 & 22.6 & 10.5 & 30.5 \\
\hline Community metabolism & \multicolumn{3}{|c|}{$n=50$} & \multicolumn{3}{|c|}{$n=42$} & \multicolumn{3}{|c|}{$n=52$} & \multicolumn{3}{|c|}{$n=49$} \\
\hline Probability of no effect & 92 & 83.4 & 100 & 84 & 67.8 & 97.8 & 96.1 & 90.7 & 100 & 95.8 & 87.7 & 100 \\
\hline Probability of slight effect & 3.9 & 0 & 10.5 & 2.47 & 0 & 11.4 & 2.0 & 0 & 8.5 & 1.9 & 0 & 5.8 \\
\hline Probability of clear effect & 4.1 & 0 & 10.7 & 13.5 & 1.4 & 30.7 & 1.8 & 0 & 4.8 & 2.3 & 0 & 11 \\
\hline Fish & \multicolumn{3}{|c|}{$n=44$} & \multicolumn{3}{|c|}{$n=37$} & \multicolumn{3}{|c|}{$n=50$} & \multicolumn{3}{|c|}{$n=45$} \\
\hline Probability of no effect & 50.2 & 35.1 & 65.7 & 48.1 & 27.7 & 64.5 & 58.1 & 43.2 & 73.4 & 55.2 & 40.9 & 76.8 \\
\hline Probability of slight effect & 13.6 & 3.8 & 25.2 & 7.9 & 0 & 17.4 & 14.2 & 4.7 & 28.1 & 12.5 & 2.7 & 24 \\
\hline Probability of clear effect & 36.2 & 22.6 & 50.5 & 44 & 28.1 & 65.7 & 27.8 & 12.4 & 39.1 & 32.2 & 11.7 & 47 \\
\hline Insects & \multicolumn{3}{|c|}{$n=52$} & \multicolumn{3}{|c|}{$n=52$} & \multicolumn{3}{|c|}{$n=52$} & \multicolumn{3}{|c|}{$n=52$} \\
\hline Probability of no effect & 3.6 & 0 & 7.4 & 1.7 & 0 & 5.2 & 1.7 & 1.6 & 12.3 & 9.9 & 2.1 & 21.8 \\
\hline Probability of slight effect & 7.3 & 1.7 & 12.1 & 6.8 & 0 & 13.3 & 5.1 & 0 & 8.8 & 8.0 & 1.9 & 21.6 \\
\hline Probability of clear effect & 89.1 & 83.9 & 97.9 & 91.5 & 84.4 & 97.8 & 93.2 & 81.5 & 96.1 & 82.1 & 63.1 & 93.2 \\
\hline Macrocrustacea & \multicolumn{3}{|c|}{$n=36$} & \multicolumn{3}{|c|}{$n=26$} & \multicolumn{3}{|c|}{$n=42$} & \multicolumn{3}{|c|}{$n=37$} \\
\hline Probability of no effect & 10.9 & 0 & 23 & 6.9 & 0 & 15.7 & 15.8 & 3.3 & 24.7 & 17.1 & 4.6 & 39.4 \\
\hline Probability of slight effect & 5.5 & 0 & 14 & 6.9 & 0 & 16.1 & 6.8 & 0 & 13 & 6.1 & 0 & 22.8 \\
\hline Probability of clear effect & 83.6 & 69.5 & 95.1 & 86.3 & 74.5 & 100 & 77.5 & 68.6 & 94.2 & 76.8 & 50.9 & 89.4 \\
\hline Microcrustacea & \multicolumn{3}{|c|}{$n=52$} & & $n=52$ & & & $n=52$ & & & $n=52$ & \\
\hline Probability of no effect & 1.4 & 0 & 6.9 & 1.8 & 0 & 3.9 & 15.7 & 5.9 & 23.2 & 7.5 & 2.2 & 16.4 \\
\hline Probability of slight effect & 19.8 & 6.7 & 25.7 & 5.3 & 1.9 & 15 & 12.9 & 6.3 & 22.3 & 18.7 & 7.3 & 29.3 \\
\hline Probability of clear effect & 78.8 & 70.6 & 90.5 & 92.9 & 84 & 97 & 71.3 & 62 & 83 & 73.8 & 61.9 & 85.6 \\
\hline Other macro-invertebrates & & $n=40$ & & & $n=32$ & & & $n=46$ & & & $n=39$ & \\
\hline Probability of no effect & 64.5 & 48.4 & 80.9 & 59.7 & 43 & 78.9 & 78.7 & 66.4 & 91.6 & 75.6 & 55 & 87.9 \\
\hline Probability of slight effect & 2.5 & 0 & 7.68 & 3.0 & 0 & 9.8 & 0 & 0 & 0 & 0 & 0 & 0 \\
\hline Probability of clear effect & 33 & 17.3 & 49.4 & 37.3 & 18.8 & 55.1 & 21.3 & 8.4 & 34 & 24.4 & 12.1 & 45.5 \\
\hline Rotifers & & $n=52$ & & & $n=48$ & & & $n=52$ & & & $n=52$ & \\
\hline Probability of no effect & 63.9 & 50.3 & 75.8 & 62 & 46.4 & 75.9 & 67.1 & 54.7 & 78.5 & 68.7 & 59.3 & 85.3 \\
\hline Probability of slight effect & 9.7 & 2.4 & 16.7 & 10.1 & 1.9 & 19 & 3.6 & 0 & 9.3 & 5.7 & 0 & 12.8 \\
\hline Probability of clear effect & 26.4 & 17.3 & 39.9 & 27.9 & 16.7 & 45.8 & 29.3 & 16.7 & 41.6 & 25.6 & 11.1 & 34.8 \\
\hline
\end{tabular}

occurring on all of the grouped endpoints, with the exception of molluscs, which were predicted to have a PEC of $20 \mu \mathrm{g} / \ell$. In the prediction of Ansara-Ross et al. (2008) for bromoxynil, no clear effects were indicated within the grouped endpoints but this study indicated high probabilities of effects occurring on community metabolism, macrophytes, periphyton, phytoplankton and zooplankton classes. Additionally, slightly lower probabilities were yielded for molluscs, macro-crustaceans and insects.

\section{CONCLUSION}

The purpose of the implementation of the PRIMET and PERPEST models in another irrigation scheme within South
Africa was to test whether the models can be used with the same measure of success that was found for the Crocodile River (West) Irrigation Scheme. The PRIMET model was used effectively to predict the preliminary risk to the aquatic environment, as the model is user-friendly, while the necessary input variables are easily available in various sources. The PRIMET model was run for 22 pesticide-crop combinations currently used within the VHIS. Of these, 13 pesticidecrop combinations indicated no risk for effects to the aquatic environment, while the possible and definite risk categories accounted for 6 and 3 pesticide-crop combinations, respectively. Deltamethrin, parathion and paraquat were identified as posing the highest risk to the aquatic ecosystem in both the 
TABLE 6

The percentage probability (Prob) of effect classes (No Effect, Slight Effect and Clear Effect) for 8 grouped ecological endpoints with the respective lower $(5 \% \mathrm{CL})$ and upper $(95 \% \mathrm{CL})$ confidence interval for each of the herbicides calculated using PERPEST ( $n=$ number of studies used in analysis)

\begin{tabular}{|c|c|c|c|c|c|c|c|c|c|c|c|c|c|c|c|}
\hline \multirow{4}{*}{\begin{tabular}{|l|} 
Herbicides \\
Community metabolism \\
Probability of no effect \\
\end{tabular}} & \multicolumn{3}{|c|}{$\begin{array}{l}\text { Acetochlor } \\
(16.29 \mu \mathrm{g} / \ell)\end{array}$} & \multicolumn{3}{|c|}{$\begin{array}{l}\text { Paraquat } \\
(1.7 \mu \mathrm{g} / \ell)\end{array}$} & \multicolumn{3}{|c|}{$\begin{array}{c}\text { Terbuthylazine } \\
(2.878 \mu \mathrm{g} / \ell)\end{array}$} & \multicolumn{3}{|c|}{$\begin{array}{l}\text { Bromoxynil } \\
(4.5 \mu \mathrm{g} / \ell)\end{array}$} & \multicolumn{3}{|c|}{$\begin{array}{l}\text { Trifluralin } \\
(6.27 \mu \mathrm{g} / \ell)\end{array}$} \\
\hline & Prob & $\begin{array}{l}5 \% \\
\mathrm{CL}\end{array}$ & $\begin{array}{c}95 \% \\
C L\end{array}$ & Prob & $\begin{array}{l}5 \% \\
\mathrm{CL}\end{array}$ & $\begin{array}{c}95 \% \\
\mathrm{CL}\end{array}$ & Prob & $\begin{array}{l}5 \% \\
C L\end{array}$ & $\begin{array}{c}95 \% \\
\mathrm{CL}\end{array}$ & Prob & $\begin{array}{l}5 \% \\
\mathrm{CL}\end{array}$ & $\begin{array}{c}95 \% \\
\mathrm{CL}\end{array}$ & Prob & $\begin{array}{l}5 \% \\
\mathrm{CL}\end{array}$ & $\begin{array}{c}95 \% \\
\mathrm{CL}\end{array}$ \\
\hline & \multicolumn{3}{|c|}{$n=45$} & \multicolumn{3}{|c|}{$n=31$} & \multicolumn{3}{|c|}{$n=53$} & \multicolumn{3}{|c|}{$n=44$} & \multicolumn{3}{|c|}{$n=10$} \\
\hline & 21.5 & 8.1 & 38.8 & 79.5 & 60.4 & 93.3 & 51.9 & 35.5 & 66.6 & 6.2 & 1.6 & 12.4 & 92.1 & 43 & 100 \\
\hline light effect & 1.9 & 0 & 5.5 & 14.9 & 3.2 & 33.9 & 23.5 & 11.9 & 38.4 & 4.3 & 0 & 13.1 & 7.9 & 0 & 59.2 \\
\hline Probability of clear effect & 76.6 & 60.2 & 89.2 & 5.6 & 0 & 12.6 & 4.6 & 15.2 & 37 & 89.5 & 78.6 & 97.2 & 0 & 0 & 0 \\
\hline Fish and tadpoles & \multicolumn{3}{|c|}{$n=5$} & \multicolumn{3}{|c|}{$n=2$} & \multicolumn{3}{|c|}{$n=7$} & \multicolumn{3}{|c|}{$n=1$} & \multicolumn{3}{|c|}{$n=2$} \\
\hline Probability of no effect & 0 & 0 & 0 & 49.9 & 0 & 100 & 84.8 & 49.3 & 100 & 0 & 0 & 0 & 50 & 0 & 100 \\
\hline Probability of slight effect & 0 & 0 & 0 & 0 & 0 & - & 0 & 0 & 0 & 0 & 0 & 0 & 0 & 0 & 0 \\
\hline Probability of clear effect & 00 & 100 & 100 & 50.1 & 0 & 100 & 15.2 & 0 & 50.8 & 100 & 100 & 100 & 50 & 0 & 100 \\
\hline $\begin{array}{l}\text { Macrocrustaceans and } \\
\text { insects }\end{array}$ & \multicolumn{3}{|c|}{$n=1$} & \multicolumn{3}{|c|}{$n=8$} & \multicolumn{3}{|c|}{$n=8$} & \multicolumn{3}{|c|}{$n=5$} & \multicolumn{3}{|c|}{$n=4$} \\
\hline Probability of no effect & 40.1 & 0 & 100 & 62.4 & 22.2 & 100 & 48.2 & 0 & 100 & 49.2 & 0 & 100 & 75 & 0 & 100 \\
\hline ght effect & 0 & 0 & 0 & 12.5 & 0 & 40 & 14.6 & 0 & 51 & 0 & 0 & 0 & 0 & 0 & 0 \\
\hline Probability of clear effect & 59.9 & 0 & 100 & 25.1 & 0 & 60.2 & 37.2 & 0 & 73.2 & 50.8 & 0 & 100 & 25 & 0 & 100 \\
\hline Macrophytes & \multicolumn{3}{|c|}{$n=16$} & \multicolumn{3}{|c|}{$n=15$} & \multicolumn{3}{|c|}{$n=28$} & & $n=15$ & & & $n=9$ & \\
\hline Probability of no effect & 18.9 & 0 & 45.3 & 74.6 & 51 & 95 & 82.8 & 66.7 & 94.7 & 15.5 & 0 & 36.8 & 66.6 & 25.2 & 92.8 \\
\hline Probability of & 0 & 0 & 0 & 0 & 0 & 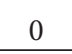 & 2.3 & 0 & 7.9 & 0 & 0 & 0 & 0 & 0 & 0 \\
\hline Probability of clear effect & 1.1 & 57 & 100 & 25.4 & 4.9 & 50.1 & 14.9 & 3.7 & 29.7 & 84.5 & 63.6 & 100 & 33.4 & 7.2 & 75.5 \\
\hline Molluscs & & $n=3$ & & & $n=2$ & & & $n=7$ & & & $n=3$ & & & $n=0$ & \\
\hline Probability & 66.6 & 0 & 100 & 100 & 100 & 100 & 100 & 100 & 100 & 64.1 & 0 & 100 & 0 & 0 & 0 \\
\hline Probability of slight effect & 0 & 0 & 0 & 0 & 0 & 0 & 0 & 0 & 0 & 0 & 0 & 0 & 0 & 0 & 0 \\
\hline Probability o & 3.4 & 0 & 100 & 0 & 0 & 0 & 0 & 0 & 0 & 35.9 & 0 & 100 & 0 & 0 & 0 \\
\hline Periphyton & & $n=$ & & & $n=$ & & & $n=36$ & & & $n=1$ & & & $n=3$ & \\
\hline Probability o & 16.4 & 3.9 & 46.9 & 85.1 & 41.2 & 100 & 55.4 & 35.9 & 75.4 & 22.9 & 2.9 & 46.4 & 100 & 100 & 100 \\
\hline Probability of slight effect & 0 & 0 & 0 & 0 & 0 & 0 & 7.2 & 0 & 17.5 & 0 & 0 & 0 & 0 & 0 & 0 \\
\hline Probability of clear effect & 83.6 & 55.3 & 96.1 & 14.9 & 0 & 59.4 & 37.3 & 17.6 & 54.7 & 77.1 & 53.7 & 100 & 0 & 0 & 0 \\
\hline Phytoplankton & & $n=13$ & & & $n=15$ & & & $n=33$ & & & $n=12$ & & & $n=5$ & \\
\hline Probability of no effect & 7.6 & 0 & 25 & 87 & 67.3 & 100 & 74.9 & 58.8 & 88.7 & 10.1 & 0 & 29.2 & 80.1 & 50 & 100 \\
\hline Probability of slight effect & 0 & 0 & 0 & 13 & 0 & 3 & 1 & 0 & 18.3 & 0 & 0 & 0 & 19.9 & 0 & 50 \\
\hline Probability of clear effect & 92.4 & 75 & 100 & 0 & 0 & 0 & 16.5 & 4.5 & 32.2 & 89.9 & 71.4 & 100 & 0 & 0 & 0 \\
\hline Zooplankton & & $n=14$ & & & $n=16$ & & & $n=33$ & & & $n=13$ & & & $n=5$ & \\
\hline Probability of no effect & 7.0 & 0 & 22.2 & 92.6 & 67.8 & 100 & 90.1 & 74 & 100 & 7.8 & 0 & 27.5 & 100 & 100 & 100 \\
\hline Probability of slight effect & 0 & 0 & 0 & 0 & 0 & 0 & 0 & 0 & 0 & 0 & 0 & 0 & 0 & 0 & 0 \\
\hline Probability of clear effect & 93 & 77.9 & 100 & 7.4 & 0 & 32.3 & 9.4 & 0 & 26.3 & 92.2 & 72.6 & 100 & 0 & 0 & 0 \\
\hline
\end{tabular}

PRIMET and PERPEST models. The PERPEST model especially predicted a high probability of effects on crustaceans and insects. As mentioned by Ansara-Ross et al. (2008) this method of risk assessment is a significant improvement on the current safety factors or simulation models used.

Of the 22 pesticide-crop combinations tested in this study, four of these pesticide-crop combinations were also tested in the study undertaken by Ansara-Ross et al. (2008) in the Crocodile River (West) Irrigation Scheme. The results from this study corresponded with their results, with the pesticides falling in the same risk categories. However, the ETR ratio was higher in the VHIS than in the Crocodile River (West). This is probably due to differences in the physical scenario and not differences in the pesticide properties. Also, the VHIS is a larger irrigation scheme and the results for suspended sediment particles indicated higher concentrations. Increased levels of suspended sediment generally result in an increased risk, as pesticides have more substrate to bind to, which can potentially affect their toxicity.

These models could therefore be useful tools to educate farmers and stakeholders on the effects of pesticides on 
non-target organisms. They provide information on the specific risks of a pesticide at a given application rate within the specific scenario, thus making it possible for the farmers to choose the lowest risk pesticides or to decrease their pesticide application rates to ensure the least amount of risk to the aquatic ecosystem. The confidence of the models could be increased if local bioassay results are incorporated into the PERPEST database. However, it must be remembered that these models only provide the risk of pesticides to the VHIS due to spray drift. The potential is there that these risks are an underestimation, as runoff and drainage from the VHIS can potentially increase the risk of pesticides being transported to the Harts River. Therefore it is important that these identified risks be validated through field monitoring of pesticide exposure and effects.

\section{ACKNOWLEDGEMENTS}

The authors would like to thank the National Research Foundation (NRF) for the funding of this project as well as the University of Johannesburg. We would also like to thank Martin Ferreira, Linette Ferreira, Zola Visser, Ruan Gerber and Natalie Degger for all their help with the fieldwork.

\section{REFERENCES}

ANSARA-ROSS TM, WEPENER V, VAN DEN BRINK PJ and ROSS MJ (2008) Probabilistic risk assessment of the environmental impacts of pesticides in the Crocodile (west) Marico catchment, North-West Province. Water SA 34 (5) 637-644.

ATSDR (AGENCY FOR TOXIC SUBSTANCES AND DISEASE REGISTRY) (2003) Toxicological profile for atrazine. US Department of Health and Human Services. Atlanta, Georgia, USA.

BOLLMOHR S, DAY JA and SCHULZ R (2007) Temporal variability in particle-associated pesticide exposure in a temporarily open estuary, Western Cape, South Africa. Chemosphere 68 479-488.

BROCK TCM, LAHR J and VAN DEN BRINK PJ (2000a) Ecological risks of pesticides in freshwater ecosystems. Part 1: Herbicides. Report 088. Alterra Green World Research, Wageningen.

BROCK TCM, VAN WIJNGAARDEN RPA and VAN GEEST GJ (2000b) Ecological risks of pesticides in freshwater ecosystems. Part 2: Insecticides. Report 089. Alterra Green World Research, Wageningen.

CAMPBELL PJ, ARNOLD DJS, BROCK TCM, GRANDY NJ, HEGER W, HEIMBACH F and MAUND SJ (1999) Guidance Document on Higher tier Aquatic Risk Assessment for Pesticides (HARAP). SETAC-Europe, 1 Brussels.

COORS A, KUCKELKORN J, HAMMERS-WIRTZ M and STRAUSS $\mathrm{T}$ (2006) Application of in-situ bioassays with macrophytes in aquatic mesocosm studies. Ecotoxicology 15 583-591.

DAMALAS CA and ELEFTHEROHORINOS IG (2011) Pesticide exposure, safety issues, and risk assessment indicators. Int. J. Environ. Res. Public Health 8 1402-1419.

DOLAPTSOGLOU C, KARPOUZAS DG, MENKISSOGLUSPIROUDI U, ELEFTHEROHORINOS I and VOUDRIAS EA (2007) Influence of different organic amendments on the degradation, metabolism, and adsorption of terbuthylazine. J. Environ. Qual. 36 1793-1802.

DWAF (DEPARTMENT OF WATER AFFAIRS AND FORESTRY, SOUTH AFRICA) (2004) Lower Vaal Water Management Area: Internal Strategic Perspective (ISP). Prepared by PDNA, WRP Consulting Engineers (Pty) Ltd, WMB and Kwezi-V3 on behalf of the Directorate: National Water Resource Planning. DWAF Report No. P WMA 10/000/00/0304. Department of Water Affairs and Forestry, Pretoria.

ECOBICHON D (2001) Pesticide use in developing countries. Toxicology $16027-33$

EXTOXNET (EXTENSION TOXICOLOGY NETWORK) (2009) A Pesticide Information Project of Cooperative Extension Offices of Cornell University, University of California, Michigan State
University and Oregon State University. URL: http://extoxnet.orst. edu/ (Accessed June 2009).

HOLTERMAN HJ and VAN DE ZANDE JC (2003) IMAG Drift Calculator Version 1.1 User Manual. Draft Report. Wageningen, the Netherlands.

HUANG H and XIONG Z (2009) Toxic effects of cadmium, acetochlor and bensulfuron-methyl on nitrogen metabolism and plant growth in rice seedlings. Pestic. Biochem. Physiol. 94 64-67.

IUPAC (INTERNATIONAL UNION OF PURE AND APPLIED CHEMISTRY) (2010) IUPAC Footprint Pesticide Properties Database (PPDB). URL: http://sitem.herts.ac.uk/aeru/iupac/ (Accessed January 2010).

JANSEN VAN VUUREN A, PRETORIUS E and BENADE N (2004) Optimal management of Vaalharts Irrigation Scheme by full implementation of water release module of the WAS programme. In: Proc. 2004 Water Institute of South Africa (WISA) Biennial Conference, 2-6 May 2004, Cape Town.

KASHIAN DR and DODSON SI (2002) Effects of common-use pesticides on developmental and reproductive processes in Daphnia. Toxicol. Ind. Health 18 225-235.

KOELMANS AA, VAN DER HEIJDE A, KNIJFF L and AALDERINK RH (2001) Modelling feedbacks between eutrophication and organic contaminant fate and effects in aquatic ecosystems. A review. Water Res. 35 3517-3536.

LONDON L, DALVIE MA, NOWICKI A and CAIRNCROSS E (2005) Approaches for regulating water in South Africa for the presence of pesticides. Water SA 31 (1) 53-59.

NEMETH-KONDA L, FULEKY GY, MOROVJAN GY and CSOKAN $P$ (2002) Sorption behaviour of acetochlor, atrazine, carbendazim, diazinon, imidacloprid and isoproturon on Hungarian agricultural soil. Chemosphere 48 545-552.

PAN (PESTICIDE ACTION NETWORK) (2009) Pesticide Action Network (PAN) Pesticide Database. URL: www.pesticideinfo.org (Accessed June 2009).

RASCHKE AM and BURGER AEC (1997) Risk Assessment as a management tool used to assess the effect of pesticide use in an irrigation system, situated in a semi-desert region. Arch. Environ. Contam. Toxicol. 32 42-49.

RELYEA R (2009) A cocktail of contaminants: how mixtures of pesticides at low concentrations affect aquatic communities. Oecologia $159363-376$.

SATAPORNVANIT K, BAIRD DJ, LITTLE DC, MILWAIN GK, VAN DEN BRINK PJ, BELTMAN WHJ, NOGUEIRA AJA, DAAM MA, DOMINGUES I, KODITHUWAKKU SS, PERERA MWP, YAKUPITIYAGE A, SURESHKUMAR SN and TAYLOR GJ (2004) Risks of pesticide use in aquatic ecosystems adjacent to mixed vegetable and monocrop fruit growing areas in Thailand. Australas. J. Ecotoxicol. 10 85-95.

SCHROER AFW, BELGERS JDM, BROCK TCM, MATSER AM, MAUND SJ and VAN DEN BRINK PJ (2004) Comparison of laboratory single species and field population-level effects of the pyrethroid insecticide $\lambda$-cyhalothrin on freshwater invertebrates. Arch. Environ. Contam. Toxicol. 46 324-335.

SCHULZ R (2001) Comparison of spray-drift- and runoff-related input of azinphos-methyl and endosulfan from fruit orchards into the Lourens River, South Africa. Chemosphere 45 543-551.

SCHULZ R (2004) Field studies on exposure, effects and risk mitigation of aquatic nonpoint-source insecticide pollution - a review. J. Environ. Qual. 33 419-448.

SOLOMON KR, GIDDINGS JM AND MAUND SJ (2001) Probabilistic risk assessment of cotton pyrethroids. I. Distribution analyses of laboratory aquatic toxicity data. Environ. Toxicol. Chem. 20 652-659.

TOMLIN CDS (2000) The Pesticide Manual (12 $2^{\text {th }}$ edn.) British Crop Protection Council, Farnham, UK.

TRAAS TP, JANSE JH, ALDENBERG T and BROCK TCM (1998) A food web model for fate, direct and indirect effects of Dursban 4E (a.i. chlorpyrifos) in freshwater microcosms. Aquat. Ecol. 32 179-190.

USEPA (UNITED STATES ENVIRONMENTAL PROTECTION AGENCY) (1996) Reregistration Eligibility Decision (RED). EPA 738-R-95-040. USEPA, Washington, DC. 
USEPA (UNITED STATES ENVIRONMENTAL PROTECTION AGENCY) (1999) Persistent Bioaccumulative Toxic (PBT) Chemicals; Final Rule. Federal Register. 40 CFR Part 372. Friday October 29, 1999. USEPA, Washington, DC.

USEPA (2009) AQUatic toxicity Information REtrieval Database (AQUIRE). U.S. Environmental Protection Agency, Washington D.C., Office of Research and Development National Health and Environmental Effects Research Laboratory, Mid-Continent Ecological Division, Duluth, MN, USA. URL: http://www.epa.gov/ med/databases/aquire.html (Accessed June 2009).

VAN DEN BRINK PJ, ROELSMA J, VAN NES EH, SCHEFFER M and BROCK TCM (2002) PERPEST model, a case-based reasoning approach to Predict Ecological Risks of PESTicides. Environ. Toxicol. Chem. 21 (11) 2500-2506.

VAN DEN BRINK PJ, TER HORST MMS, BELTMAN WHJ,

VLAMING J and VAN DEN BOSCH H (2005) PRIMET Version 1.0, Manual and Technical Description. Alterra Report No. 1185.
Alterra, Wageningen, The Netherlands.

VAN DEN BRINK PJ, BROWN CD and DUBUS IG (2006) Using the expert model PERPEST to translate measured and predicted pesticide exposure data into ecological risks. Ecol. Model. 191 106-117. VAN DEN BRINK PJ, BAVECO JM, VERBOOM J and HEIMBACH F (2007) An individual-based approach to model spatial population dynamics of invertebrates in aquatic ecosystems after pesticide contamination. Environ. Toxicol. Chem. 26 (10) 2226-2236.

VAN DER WERF HMG (1996) Assessing the impacts of pesticides on the environment. Agric. Ecosyst. Environ. 60 80-96.

VAN NES EH and VAN DEN BRINK PJ (2003) PERPEST Version 1.0, Manual and Technical Description: A Model that Predicts the Ecological Risks of PESTicides in Freshwater Ecosystems. Alterra Report No. 787. Alterra, Wageningen, The Netherlands.

WEPENER V and VERMEULEN LA (2005) A note on the concentrations and bioavailability of selected metals in sediments of Richards Bay Harbour, South Africa. Water SA 31 (4) 589-596. 
http://dx.doi.org/10.4314/wsa.v39i5.3 Available on website http://www.wrc.org.za

ISSN 0378-4738 (Print) = Water SA Vol. 39 No. 5 October 2013 ISSN 1816-7950 (On-line) = Water SA Vol. 39 No. 5 October 2013 